\title{
Regulator of G-Protein Signaling 7
}

National Cancer Institute

\section{Source}

National Cancer Institute. Regulator of G-Protein Signaling 7. NCI Thesaurus. Code C143120.

Regulator of G-protein signaling 7 (495 aa, $\sim 58 \mathrm{kDa}$ ) is encoded by the human RGS7 gene. This protein plays a role in the promotion of $\mathrm{G}$ alpha protein GT Pase activity. 